\title{
A Comparative Study on Competitiveness of KIBS in HK and Singapore
}

\author{
Wenying Deng \\ School of Economics, Jinan University, Guangzhou, China \\ Email: salicedengwy@163.com
}

How to cite this paper: Deng, W.Y. (2016) A Comparative Study on Competitiveness of KIBS in HK and Singapore. Modern Economy, 7, 1086-1095.

http://dx.doi.org/10.4236/me.2016.710110

Received: August 24, 2016

Accepted: September 10, 2016

Published: September 13, 2016

Copyright (@) 2016 by author and Scientific Research Publishing Inc. This work is licensed under the Creative Commons Attribution International License (CC BY 4.0).

http://creativecommons.org/licenses/by/4.0/

(c) (†) Open Access

\begin{abstract}
The purpose of this paper is to analyze the competitiveness of Knowledge Intensive Business Services (KIBS) in Hong Kong and Singapore from 2005 to 2015. In terms of methodology, we employ three indices-Export Market Share (MS), Revealed Comparative Advantage (RCA) and Relative Trade Advantage (RTA) to measure competitiveness in selected sectors. Results show that although Hong Kong and Singapore have taken up greater world market share, neither of them shows strong comparative advantage in overall KIBS. Based on the RCA index, Singapore has stronger comparative advantage than Hong Kong on overall KIBS, while the values of RTA index reveal reverse conclusion. Both the RCA and the RTA indices exhibit the consistent result that the greatest competitive advantage is earned by financial services sector in Hong Kong as well as Singapore. Of particular note, according to the values of two revealed comparative advantage indices, neither Hong Kong nor Singapore has comparative advantage in charge for the use of intellectual property sector.
\end{abstract}

\section{Keywords}

Comparative Advantage, KIBS, Hong Kong, Singapore

\section{Introduction}

Since 1980s, both the development level and trade scale of international service trade have been improving rapidly throughout the world. In 2015, world service exports amounted to 4.8 trillion dollars, which contributed about 7 percent to the world GDP. The significance of KIBS in service trade development and structure upgrade has been enhanced, and KIBS is becoming the crucial source of service competitiveness in developed countries, whose KIBS accounting considerable proportion for GDP. Over the last ten years, world exports in KIBS had doubled, and the average annual growth rate 
had outperformed total service exports as well as goods exports.

The strategic role of services and KIBS has been emphasized by many scholars these years. Abdulkadir, Mahmut \& Abdullah [1] proposed that "Services sector and trade in services perform as the leading sector and as the engine of growth". Muller \& Zenker [2] stated that "the increasing importance of Knowledge Intensive Business Services constitutes one of the characteristics of the raise of the so-called 'Knowledge Economy"'. Scholars including Muller \& Zenker, Ciriaci, Montresor \& Palma [3] and D'Antone \& Santos [4] concentrated on studying the role that KIBS played in the innovation system, and their researches concluded that KIBS could contribute to the development of innovation. Therefore, for sustainable economy growth and industrial structure upgrade, improving competitiveness in service trade, especially in KIBS trade is crucial to individual economy.

Either Hong Kong or Singapore is a "small open economy" and belongs to the "Four Asian Tigers". Besides they both being global financial centers (according to Global Financial Center Index in 2014, New York, London, Hong Kong and Singapore are the four largest financial center), striking similarities exist in such many aspects as geographical proximity, free trade policies, and analogous foreign trade development patterns. In 2015, 20 percent of Hong Kong's GDP growth came from KIBS, while that proportion of Singapore exceeded 50 percent. Since knowledge intensive business services have strategic role in Hong Kong and Singapore, and comparison between them in terms of KIBS comparative advantage is rare, this article can make up for this vacancy.

Significance and innovation of this article lies in two aspects. Firstly, on the basis of the previous analysis, we redefine the definition of KIBS and determine the categories that belong to KIBS. Secondly, we apply the latest data and three indices to calculate and compare competitiveness of overall KIBS and each KIBS sectors in Hong Kong and Singapore.

\section{Definition}

\subsection{Services}

Balance of Payments and International Investment Position Manual, Sixth Edition (BPM6, 2009) explains services and its distinction from goods as follows:

Services are the result of a production activity that changes the conditions of the consuming units, or facilitates the exchange of products or financial assets. Services are not generally separate items over which ownership rights can be established and cannot generally be separated from their production. However, some knowledge-capturing products, such as computer software and other intellectual property products, may be traded separately from their production, like goods.

According to UNCTAD and WTO, services are classified into the following four categories: goods-related services, transport, travel and other services. Other services are further disaggregated into: construction, insurance and pension services, financial services, charges for the use of intellectual property, telecommunications, computer 
and information services, other business services, personal, cultural and recreational services, government goods and services, and services not allocated.

\subsection{KIBS}

There is no widely accepted definition about Knowledge Intensive Business Services now. Miles et al. [5] put forward that "KIBS are services that rely heavily upon professional knowledge, either supply products which are themselves primarily sources of information and knowledge to their users, or use their knowledge to produce services which are intermediate inputs to their clients' own knowledge generating and information processing activities". Muller \& Zenker thought "KIBS might be defined as 'consultancy' firms in a broad sense, more generally speaking, KIBS could be described as firms performing, mainly for other firms, services encompassing a high intellectual value-added". Wood [6] considered KIBSs to be "private sector firms that offer specialist professional, consultancy, and outsourcing services to other organizations". Li \& Zhou [7] summarized domestic and foreign studies, defined KIBS as services for the production, reserves, use and proliferation of knowledge and technology, which had high degree of interaction and dependence.

Referring to previous researches about KIBS definition, we define KIBS as services which rely heavily on professional knowledge as well as services that promote production, reverses, use and proliferation of knowledge and technology. According to the updated statistical classification based on UNCTAD, this article regards the following five categories as KIBS: insurance and pension services, financial services, charges for the use of intellectual property, telecommunications, computer and information services and other business services.

\section{Methodology and Data}

Jackman, Lorde, Lowe \& Alleyne [8] argued "the theory of comparative advantage is probably one of the most important concepts in international trade theory, and the concept of comparative advantage is commonly employed to evaluate patterns of trade and export specialization". Two prominent traditional trade theories about comparative advantage are the Ricardian theory and the Heckscher-Olin (HO) theory. Ricardian theory posits that a comparative advantage exists amongst countries because of differences in relative costs for production. Instead, HO theory assumes a country's advantage is due to differences in factor prices across countries. According to HO theory, a country's comparative advantage is determined by its relative factor scarcity, which means a country will export products that use its abundant and cheap factor(s) of production and import products that use its scarce factor(s) to gain comparative advantage.

Domestic and foreign scholars have paid high attention to measure international comparative advantage these years. The existing researches are mainly about comparison between countries in total goods, total services or selected trade sectors in goods or services. Empirical studies regarding Knowledge Intensive Business Services (KIBS) are relatively rare. Because relative prices under autarky are unobservable, scholars have 
developed several indices to measure comparative advantage. General indices include: MS (Export Market Share), TC (Trade Specialization Coefficient) and RCA (Revealed Comparative Advantage). Since being proposed by Balassa [9], RCA has been widely used in evaluating comparative advantage, however, with certain shortcomings. One issue, as pointed out by Greenaway \& Milner [10] is that "the Balassa index of revealed comparative advantage is biased from the perspective that it just take exports into account and ignores the influence of imports and, as such, implies possible over or underestimation of any underlying comparative advantage or disadvantage", moreover, asymmetry problem exists. For a more comprehensive and objective measurement method, many scholars including Balassa have modified and expanded RCA index since 1980's. For instance, NXRCA-Net Export Revealed Comparative Advantage Index [11], RTA-Relative Trade Advantage index [12], and RXA-Revealed Export Advantage index [13]. Kang [14] concluded that RTA seemed to be both objective and symmetrical, which was more acceptable and valid in measuring the comparative advantage.

Due to data availability and index validity, in methodology, we employ MS, RCA and RTA index to evaluate comparative advantage and disadvantage in KIBS for Hong Kong and Singapore. The data for the calculations were provided by UNCTAD online database [15] from 2005 to 2015 (Hong Kong's service trade data for 2015 is not complete, so indices values are correspondingly lacked).

\section{Index Description}

Firstly, Export Market Share (MS) monitors a country's export performance compared with the total world's exports. The index for country $i$ commodity $j$ is calculated as follows:

$$
M S_{i j}=X_{i j} / X_{w j}
$$

where: $X_{i j}$-country $i$ s exports of commodity $j ; X_{w j}$-world exports of commodity $j$; $M S_{i j}$ - export market share of country $i$ in commodity $j$. The greater value of the index indicates stronger competitiveness of country $I$ in the commodity $j$. The value of MS ranges from 0 to 1 .

Secondly, RCA index, which is measured by the product's share in the country's exports in relation to its share in the world trade. The index for country $i$ commodity $j$ is calculated as:

$$
R C A_{i j}=\frac{X_{i j} / X_{i}}{X_{w j} / X_{w}}
$$

where: $X_{i j}$ and $X_{w j}$ are as defined in Equation (1), $X_{i}$-total exports of country $i$; $X_{w}$-total world exports; $R C A_{i j}$ - revealed comparative advantage of country $i$ in commodity $j$. We use the classification system by Hinloopen and Marrewijk [16] to classify SIDS according to their degree of comparative advantage. Class a: $0<R C A_{i j} \leq 1$ are countries without a comparative advantage; Class b: $1<R C A_{i j} \leq 2$ are countries with a weak comparative advantage; Class c: $2<R C A_{i j} \leq 4$ are countries with a medium comparative advantage; and Class $\mathrm{d}: R C A_{i j}>4$ are countries with a strong com- 
parative advantage.

In order to prevent the problem of asymmetry, $R T A$ index is employed, which can be expressed as the differences between $R C A$ and the revealed import advantage:

$$
R T A_{i j}=\frac{X_{i j} / X_{i}}{X_{w j} / X_{w}}-\frac{M_{i j} / M_{i}}{M_{w j} / M_{w}}
$$

where variables are as defined in Equations (1) and (2), but $M$ represents imports. Under this approach, positive values indicate a comparative advantage whereas negative values indicate comparative disadvantage.

\section{Empirical Findings}

In the first stage of the analysis, the MS index is calculated for each country (see Table 1). The data reveals that Both Hong Kong and Singapore are playing increasingly significant role in world KIBS, while compared with Hong Kong, Singapore take up greater market share, and hold higher comparative advantage. During the period 2005-2015, Singapore's KIBS revealed steady improvement on export market share, and the share of world exports rose from $1.44 \%$ to $2.85 \%$. However, Hong Kong's export market share improved slightly over the last decade, which was merely $1.43 \%$ in 2014 , about half of Singapore.

In the second stage of analysis, we calculate RCA index then. In this paper, Revealed Comparative Advantage (RCA) analysis has been undertaken at both overall KIBS and each KIBS category level.

Table 2 reveals that Singapore has changed its competitiveness status from being disadvantageous to advantageous in KIBS in the world market since 2012, while Hong Kong never owns revealed comparative advantage in its overall KIBS. The RCA value for Hong Kong's overall KIBS increased from 0.53 in 2005 to 0.54 in 2015, which merely increased by 0.01 throughout the analyzed period. This implies that Hong Kong lacks comparative advantage in KIBS. On the other hand, RCA values of Singapore indicate that Singapore's trade position has improved continuously from 2005 to 2015. Additionally, the increase of comparative advantage is linked with the increased export market share (see Table 1 and Table 2).

Figure 1 intuitively displays revealed comparative advantage changes in each KIBS

Table 1. Values of MS index for KIBS (\%).

\begin{tabular}{cccccccccccc}
\hline & 2005 & 2006 & 2007 & 2008 & 2009 & 2010 & 2011 & 2012 & 2013 & 2014 & 2015 \\
\hline HK & 1.35 & 1.42 & 1.45 & 1.35 & 1.39 & 1.54 & 1.44 & 1.51 & 1.47 & 1.43 & - \\
Singapore & 1.44 & 1.79 & 1.84 & 1.92 & 2.04 & 2.23 & 2.35 & 2.56 & 2.82 & 2.85 & 2.85 \\
\hline
\end{tabular}

Table 2. Values of RCA index for KIBS.

\begin{tabular}{cccccccccccc}
\hline & 2005 & 2006 & 2007 & 2008 & 2009 & 2010 & 2011 & 2012 & 2013 & 2014 & 2015 \\
\hline HK & 0.54 & 0.59 & 0.63 & 0.63 & 0.58 & 0.62 & 0.61 & 0.61 & 0.56 & 0.55 & - \\
Singapore & 0.57 & 0.74 & 0.81 & 0.90 & 0.85 & 0.90 & 0.99 & 1.03 & 1.08 & 1.09 & 0.98 \\
\hline
\end{tabular}


category in Hong Kong. The index values suggest that Hong Kong only enjoys weak revealed comparative advantage for financial service, whose RCA value ranged from 1 to 2 during the analyzed period. In spite of financial service, Hong Kong has comparative disadvantage in other four categories: other business services, insurance and pension services, telecommunications, computer, and information services, and charge for the use of intellectual property. In particular, charge for the use of intellectual property shows the greatest comparative disadvantage among all categories.

Figure 2 shows the structure changes in the competitive advantages of each KIBS categories in Singapore. It demonstrates that Singapore has revealed competitive advantage in the three items below: financial services, insurance and pension services and telecommunications, computer, and information services. Of all KIBS sectors, comparative disadvantage exists in: charge for the use of intellectual property, and telecommunications,

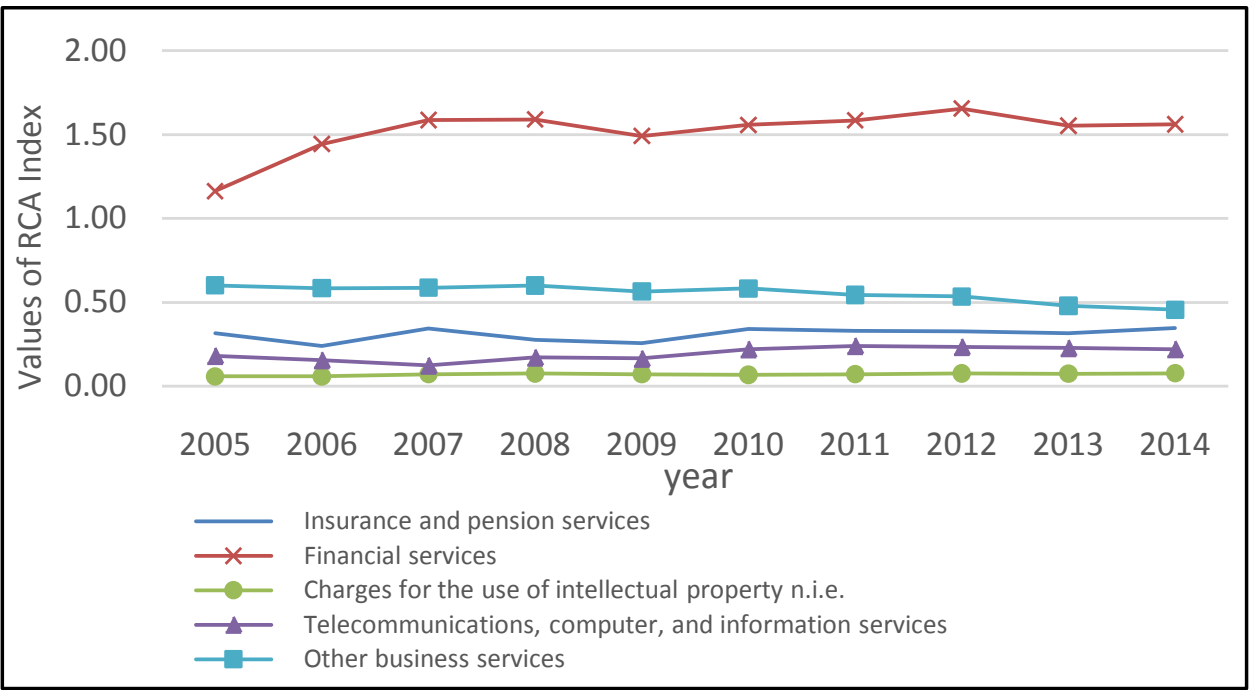

Figure 1. Values of RCA index for each category (HK).

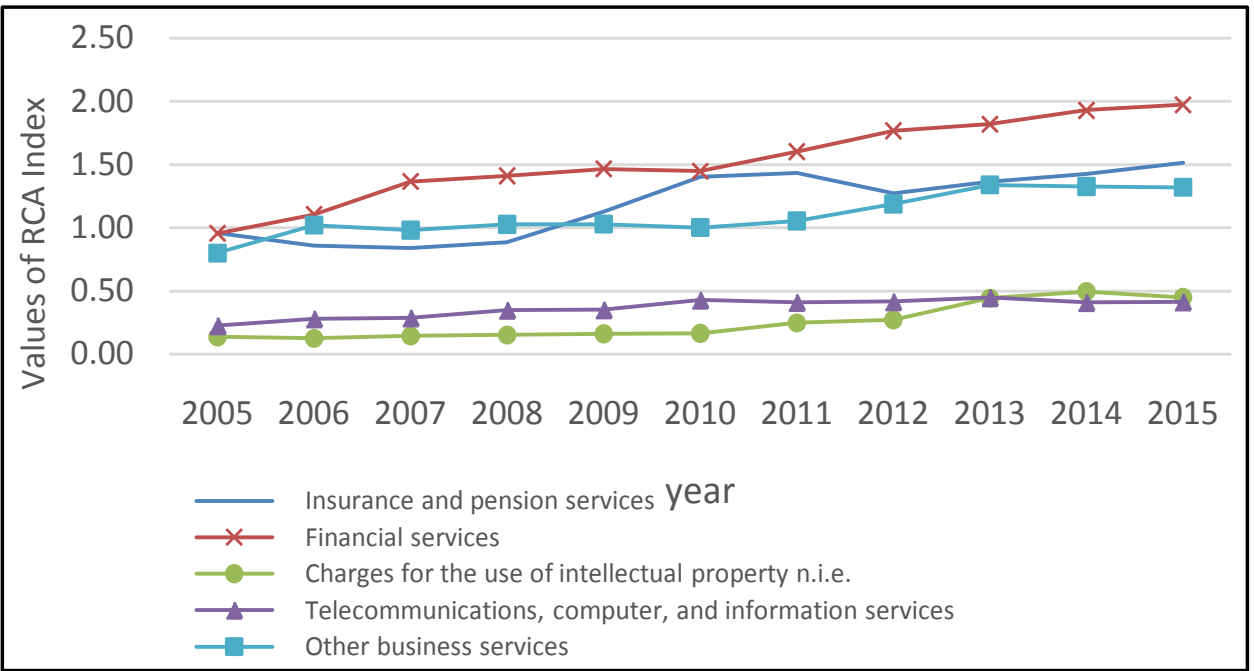

Figure 2. Values of RCA index for each category (Singapore). 
computer, and information services. From the chart, we are able to conclude that competitiveness of financial services is improving dramatically, and it indicates medium comparative advantage. On the other hand, the other two categories' RCA values ranged from 1 to 1.5 from 2005-2015, which indicated weak comparative advantage. Moreover, international competitiveness for charge for the use of intellectual property, and telecommunications, computer, and information services still need be cultivated.

Last stage, we calculate the RTA values for further assess the competitiveness. Similar to the second stage, RTA indices are calculated and analyzed at both overall KIBS and each KIBS category level.

Table 2 presents RTA values of total KIBS for two countries. According to the description of RTA index, it clarifies clearly that under this approach, the country enjoys international comparative advantage when the RTA value is positive, otherwise, it has comparative disadvantage. Looking at the mean of RTA indices over the time period, Hong Kong's average RTA is 0.24 , a positive value, while Singapore's average RTA of KIBS is negative, with a mean value -0.39 . That is to say, Hong Kong has revealed comparative advantage when KIBS imports is taken into account, however, Singapore is always at a revealed comparative disadvantage relative to the world. This implies although there is a dramatic increase on Singapore's KIBS, the domestic demand for KIBS imports expands even more.

Hong Kong's RTA indices for each KIBS sector are showed in Figure 3. From the figure we observe that, differ from the results given by RCA index, there are three KIBS sectors displaying comparative advantage. Financial services sector exhibits the most prominent revealed comparative advantage in all KIBS, followed by telecommunications, computer, and information services together with other business services. We also find that, sectors representing comparative disadvantage are insurance and pension services as well as charge for the use of intellectual property, and the later sector reveals

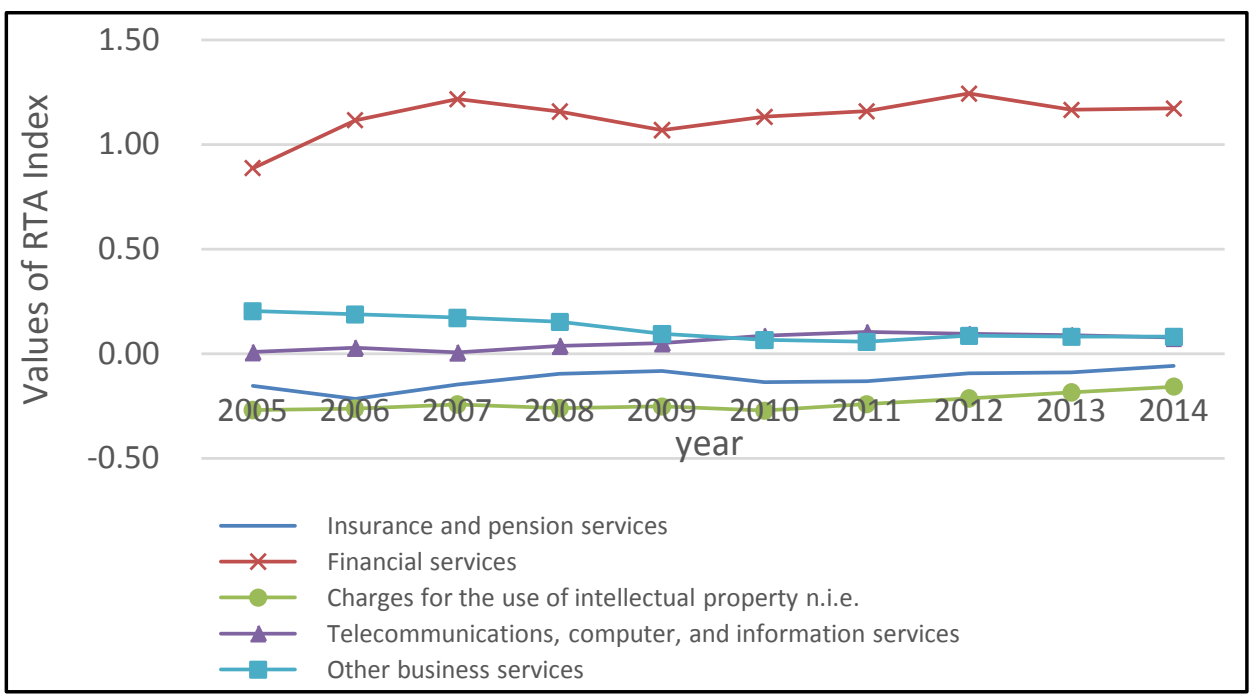

Figure 3. Values of RTA index for each category (HK). 
greatest comparative disadvantage, which consist with the RCA approach. Besides, no remarkable structure change existed over the last decade.

Learning from Figure 4, the only KIBS sector with revealed comparative advantage in Singapore is financial service, and there seems to be no comparative advantage exists in the rest four sectors, especially in charge for the use of intellectual property, which owns the greatest comparative disadvantage. The results given by RTA index are inconsistent with RCA calculation method. In detail, based on RTA values, financial services sector shows a steadily accelerating competitiveness. RTA values were always negative for other four sectors during the last decade, additionally, the mean value of Singapore's charge for the use of intellectual property sector was -2.69 , which represented unfavorable current trade position (Table 3 ).

\section{Conclusion and Future Work}

Existing body of literature on measuring the competitiveness in services for Hong Kong is very few, particularly the lack of comparative studies. To fill the gap, this paper is conducted by concentrating on competitiveness of selected KIBS sectors in Hong Kong in comparison with another "small open economy"-Singapore during the period 2005-2015.

Adopting three alternative measures of comparative advantage i.e. the MS index, the RCA index and the RTA index, following discussions can be made:

First, even though Hong Kong and Singapore have improved their export performance

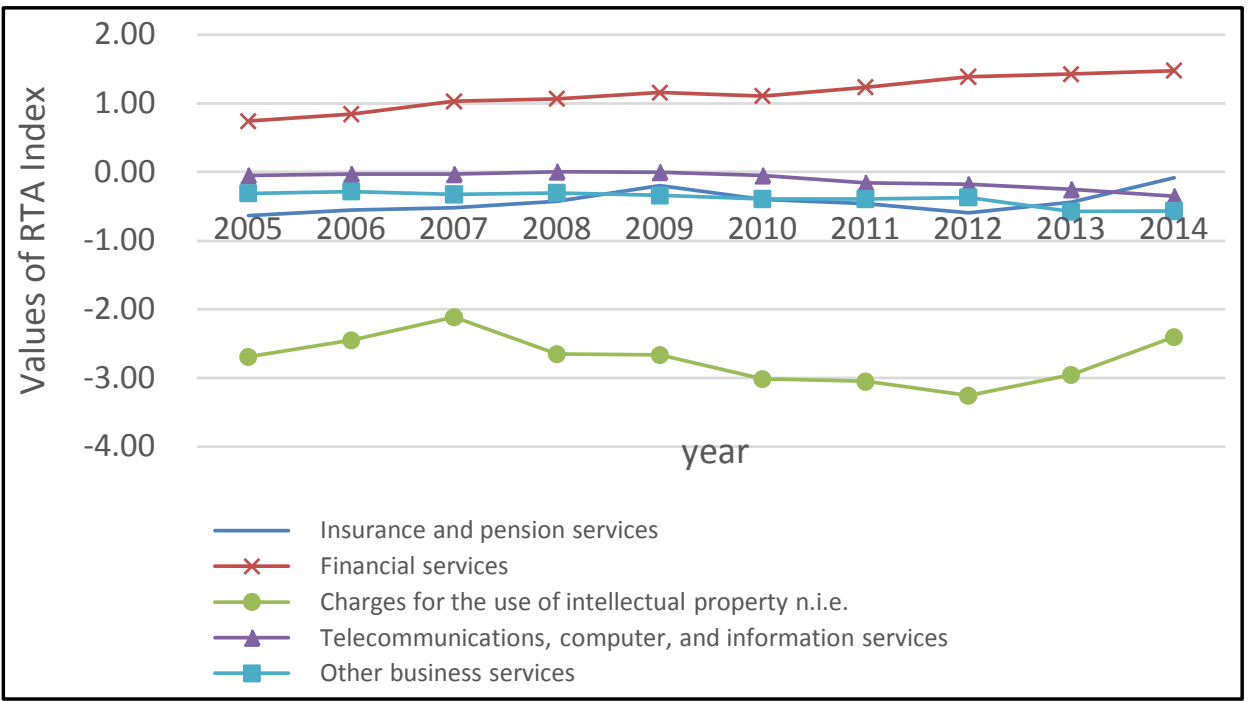

Figure 4. Values of RTA index for each category (Singapore).

Table 3. Values of RTA index for KIBS.

\begin{tabular}{cccccccccccc}
\hline & 2005 & 2006 & 2007 & 2008 & 2009 & 2010 & 2011 & 2012 & 2013 & 2014 & 2015 \\
\hline HK & 0.21 & 0.26 & 0.29 & 0.26 & 0.21 & 0.22 & 0.22 & 0.24 & 0.23 & 0.23 & - \\
Singapore & -0.50 & -0.36 & -0.25 & -0.25 & -0.33 & -0.39 & -0.36 & -0.41 & -0.52 & -0.44 & -0.53
\end{tabular}


and taken up greater world market share, neither of them shows strong comparative advantage in overall KIBS in the world market. Second, based on values of the MS index and the RCA index, Singapore has stronger competitiveness over Hong Kong in total KIBS. Third, consistent results have been given by both the RCA index and the RTA index that the biggest competitive advantage is earned by financial services sector both in Singapore and Hong Kong, and the KIBS sector with the greatest comparative disadvantage lies in charge for the use of intellectual property. Fourth, results given by RTA index indicate that Hong Kong enjoys comparative advantage in overall KIBS, however, Singapore reveals comparative disadvantage. This could be explained by their KIBS trade balance.

While this paper has provided some insight into the level of competitiveness of overall KIBS and individual KIBS sectors in Hong Kong and Singapore, it is not without its limitations. Although we evaluate the comparative advantage of each country on KIBS, but don't analyze the reasons why current competitiveness status is caused, and we don't offer suggestions on how competitiveness could be further improved. Future study could be focused on influencing factors discussion and policy suggestion.

\section{References}

[1] Hiziroglu, A., Hiziroglu, M. and Kokcam, A.H. (2013) Competitiveness in Services: Turkey versus European Union. Procedia-Social and Behavioral Sciences, 62, 436-440. http://dx.doi.org/10.1016/j.sbspro.2012.09.071

[2] Muller, E. and Zenker, A. (2001) Business Services as Actors of Knowledge Transformation: The Role of Kibs in Regional and National Innovation Systems. Research Policy, 30, 15011516. http://dx.doi.org/10.1016/S0048-7333(01)00164-0

[3] Ciriaci, D., Montresor, S. and Palma, D. (2015) Do Kibs Make Manufacturing More Innovative? An Empirical Investigation of Four European Countries. Technological Forecasting and Social Change, 95, 135-151. http://dx.doi.org/10.1016/j.techfore.2015.02.008

[4] D'Antone, S. and Santos, J.B. (2016) When Purchasing Professional Services Supports Innovation. Industrial Marketing Management, 58, 172-186.

[5] Miles, I., Kastrinos, N., Bilderbeek, R., Den Hertog, P., Flanagan, K., Huntink, W. and Bouman, M. (1995) Knowledge-Intensive Business Services: Users, Carriers and Sources of Innovation. European Innovation Monitoring System (EIMS) Reports.

[6] Wood, P. (2009) Knowledge Intensive Business Services-International Encyclopedia of Human Geography. International Encyclopedia of Human Geography, 44, 37-44. http://dx.doi.org/10.1016/B978-008044910-4.00215-7

[7] Li, X. and Zhou, C. H. (2010) The Comparison of Trade Structure and International Competitiveness on Knowledge-Intensive Business Services between China and USA. Inquiry into Economic Issues, 3, 131-137.

[8] Jackman, M., Lorde, T., Lowe, S. and Alleyne, A. (2011) Evaluating Tourism Competitiveness of Small Island Developing States: A Revealed Comparative Advantage Approach. Anatolia, 22, 350-360. http://dx.doi.org/10.1080/13032917.2011.626311

[9] Balassa, B. (1965) Trade Liberalisation and "Revealed" Comparative Advantage. The Manchester School, 33, 99-123. http://dx.doi.org/10.1111/j.1467-9957.1965.tb00050.x

[10] Greenaway, D. and Milner, C. (1993) Trade and Industrial Policy in Developing Countries. Palgrave Macmillan, UK. 
[11] Balassa, B. (1989) Comparative Advantage, Trade Policy and Economic Development. Harvester Wheatsheaf, New York.

[12] Vollrath, T.L. (1991) A Theoretical Evaluation of Alternative Trade Intensity Measures of Revealed Comparative Advantage. Weltwirtschaftliches Archiv, 127, 265-280.

http://dx.doi.org/10.1007/BF02707986

[13] Esterhuizen, D. and Van Rooyen, C.J. (1999) How Competitive Is Agribusiness in the South African Food Commodity Chain. Agrekon, 38, 744-754. http://dx.doi.org/10.1080/03031853.1999.9524885

[14] Kang, C.W. (2014) The Research Review of Revealed Comparative Advantage Index. Commercial Research, 5, 32-39.

[15] UNCTAD Online Database. http://unctadstat.unctad.org/wds/ReportFolders/reportFolders.aspx

[16] Hinloopen, J. and Marrewijk, C.V. (2001) On the Empirical Distribution of the Balassa Index. Weltwirtschaftliches Archiv, 137, 1-35. http://dx.doi.org/10.1007/BF02707598

Submit or recommend next manuscript to SCIRP and we will provide best service for you:

Accepting pre-submission inquiries through Email, Facebook, LinkedIn, Twitter, etc. A wide selection of journals (inclusive of 9 subjects, more than 200 journals)

Providing 24-hour high-quality service

User-friendly online submission system

Fair and swift peer-review system

Efficient typesetting and proofreading procedure

Display of the result of downloads and visits, as well as the number of cited articles Maximum dissemination of your research work

Submit your manuscript at: http://papersubmission.scirp.org/ 